REVIEW

\title{
Glycodelin in reproductive endocrinology and hormone-related cancer
}

\author{
M Seppälä ${ }^{1}$, H Koistinen ${ }^{1}$, R Koistinen ${ }^{1,2}$, L Hautala $^{1,2}$, P C Chiu ${ }^{3}$ and W S Yeung ${ }^{3}$ \\ Departments of ${ }^{1}$ Clinical Chemistry and ${ }^{2}$ Obstetrics and Gynaecology, University of Helsinki and Helsinki University Central Hospital, Biomedicum \\ Helsinki, 4th Floor, Helsinki O0029 HUS, Finland and ${ }^{3}$ Department of Obstetrics and Gynaecology, Queen Mary Hospital, University of Hong Kong, \\ Pokulfam Road, Hong Kong, People's Republic of China \\ (Correspondence should be addressed to M Seppälä; Email: mseppala@welho.com)
}

\begin{abstract}
Glycodelin is an endocrine-regulated glycoprotein that has significant effects on immune cells, apoptosis, reproduction, cell adhesion, differentiation and cancer. In reproduction, glycodelin contributes to capacitation and immunoprotection of spermatozoa, and it modulates sperm-oocyte binding, acrosome reaction and implantation. In endocrine-related cancer, the differentiation inducing effects of glycodelin are accompanied by growth restriction of malignant cells, decreased expression of oncogenes, increased expression of tumour suppressor genes and morphological reversion of the malignant phenotype. This review features these properties and clinical connections, highlighting the role of glycosylation in biological actions.
\end{abstract}

European Journal of Endocrinology 160 121-133

\section{Background}

After the primary structure (1), major complex type $N$-glycan structures $(2,3)$ and various biological actions (2-6) of a glycoprotein named PP14 had been resolved, the name 'glycodelin' was suggested by the Helsinki team to their collaborators $(2,3,7)$ and then accepted by the pioneers who had used other names, such as human placental organ specific $\alpha 2$-globulin, progesterone-associated endometrial protein (PAEP) and zona-binding inhibitory factor for the same glycoprotein (8-10). In addition, immunological and/or sequence similarity has been reported for PP14, a2-pregnancyassociated endometrial globulin (11) and progesteronedependent endometrial protein (12). The gene sequence of glycodelin has been documented (13), and the Human Genome Organization has registered PAEP as the official symbol of the glycodelin gene (9). Four glycoforms, namely glycodelin-S, -A, -F and -C have been characterised in reproductive tissues. They all share a common protein backbone but differ in glycosylation and biological activity $(14,15)$.

\section{Sites of synthesis}

In men, glycodelin-S is secreted from seminal vesicle glands to seminal fluid (16-18).

In women, secretory and decidualised endometrium are the major sites of glycodelin synthesis (Fig. 1) (19-22). Glycodelin is mainly secreted into uterine fluid (23) and amniotic fluid (24, 25), less to serum. Glycodelin has also been found in many other sites of the body, but not all of them actually synthesise the protein as evidenced by the absence of mRNA (Table 1). For instance, during ovarian follicle development, glycodelin-F immunoreactivity becomes detectable in the granulosa and theca cells of late secondary follicles, but only the granulosa cells express glycodelin mRNA (26). Glycodelin-F is secreted from the granulosa cells into follicular fluid and is taken up by the cumulus cells in which partial deglycosylation takes place to yield glycodelin-C (cumulus cell glycodelin) $(14,27)$.

\section{Regulation of synthesis}

Hormonal regulation of glycodelin-S synthesis in men is unknown.

\section{Progesterone and progestins}

In normal ovulatory cycles, progesterone secretion is followed by endometrial glycodelin-A synthesis in epithelial glands from 4 to 5 postovulatory days onwards $(15,38)$. Glycodelin mRNA is markedly upregulated in the mid and late secretory endometrium (Fig. 1). Glycodelin protein remains detectable in deep basal glands and the serum concentration remains elevated until days 1-3 of the next period (36). In anovulatory cycles, glycodelin serum concentration remains low throughout the cycles. In the oviduct, 

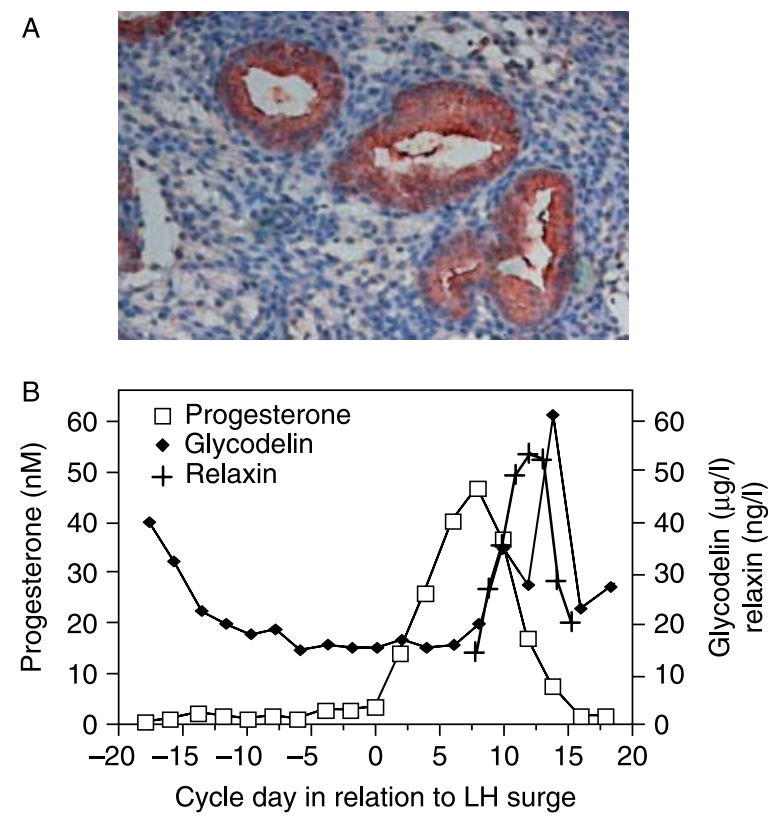

Figure 1 (A) Expression of glycodelin in human secretory endometrium and (B) its circulating levels in a normal ovulatory cycle in respect of progesterone and relaxin concentrations. Data adapted from Refs $(19,36,37)$.

glycodelin synthesis is stimulated by estrogen and progesterone (Table 2).

In early pregnancy, the rise of glycodelin-A concentration in serum and amniotic fluid peaks at 6-12 weeks gestation $(24,25)$, whereas in women with premature ovarian failure who conceived after ovum donation and embryo transfer the glycodelin levels are much lower than in the women with normal ovarian function (39). This remarkable difference suggests that the ovary itself or factors under ovarian control are involved in glycodelin secretion. More direct evidence for progesterone involvement comes from in vitro studies (Table 2). However, it seems that the effect of progesterone on glycodelin expression involves multiple factors rather than a simple pathway (see below).

\section{Human chorionic gonadotrophin}

Besides, the classic stimulatory effect of trophoblastic hCG on progesterone secretion by the corpus luteum, hCG has receptors in the endometrium where it stimulates glycodelin secretion $(40,41)$.

\section{Relaxin}

Relaxin has been suggested to be another ovarian factor contributing to glycodelin secretion. Close temporal relationship exists between relaxin and glycodelin serum profiles in late luteal phase and pregnancy. Because the glycodelin-inducing effect of progesterone is slow it has been suggested its action is based on the local inducers, such as relaxin or transcription factors that control the glycodelin promoter activity (42) (Table 2).

\section{Epigenetic regulation}

Histone acetyltransferases and histone deacetylases (HDACs) regulate gene expression through chromatin modification by catalysing transfer or removal of acetyl groups respectively. Histone deacetylase inhibitors (HDACIs), e.g. suberoylanilide hydroxamic acid (SAHA) and trichostatin (TSA) increase the level of histone acetylation, thereby turning on specific genes, including glycodelin, whose expression products induce cell growth arrest, differentiation and apoptosis (45-48). In baboon, the site of TSA action is localised to the region in the glycodelin promoter that contains the proximal Sp1 site (48). Deletions of this region have no effect on progestogen responsiveness, suggesting existence of at least two regions in the glycodelin promoter that are important for the induction of glycodelin expression. Maximal expression of the glycodelin gene

Table 1 Sites of glycodelin expression/synthesis.

\begin{tabular}{|c|c|c|c|}
\hline Tissue & Presence of protein & $\begin{array}{c}\text { Presence or absence of mRNA or } \\
\text { other evidence }^{(i)}\end{array}$ & References \\
\hline Secretory endometrium & + & + & $(19)^{(\mathrm{i})},(20)$ \\
\hline Seminal vesicle & + & + & $(16-18)$ \\
\hline Fallopian tube & + & + & $(28-30)^{(i)}$ \\
\hline Breast, breast cancer & + & + & $(31,32)$ \\
\hline Bronchus epithelium & + & nd & $(32)$ \\
\hline Ovary, ovarian cancer & + & + & $(26,33)$ \\
\hline Cumulus cells & + & - & $(26,27)$ \\
\hline Eccrine sweat glands & + & nd & (32) \\
\hline Bone marrow & + & + & $(34,35)$ \\
\hline
\end{tabular}

nd, not done; (i), labelled amino acid incorporation. 
Table 2 Regulation of glycodelin synthesis.

\begin{tabular}{|c|c|c|}
\hline Substance or factor & Type of evidence & References \\
\hline \multirow[t]{5}{*}{ Progesterone and progestins } & Endometrial Gd expression induced under progesterone influence & $(19-21,36,38)$ \\
\hline & Progestins and antiprogestins upregulate $\mathrm{Gd}$ production in vivo & (43) \\
\hline & MPA-activated PR modulates Gd promoter through the Sp1 site & $(44)$ \\
\hline & PREs present in glycodelin gene $(P A E P)$ promoter & (13) \\
\hline & Oviductal synthesis stimulated by $\mathrm{E}$ and $\mathrm{P}$ & $(29,30)$ \\
\hline HCG & Stimulation of baboon glycodelin secretion by hCG in vivo & $(41)$ \\
\hline \multirow[t]{4}{*}{ Relaxin } & $\begin{array}{l}\text { Close temporal relationship between relaxin and glycodelin serum } \\
\text { profiles in late luteal phase, with the onset of relaxin preceding } \\
\text { glycodelin secretion by } 1-2 \text { days in non-conceptive ovulatory } \\
\text { cycles and during pregnancy }\end{array}$ & (37) \\
\hline & $\begin{array}{l}\text { In fertile-aged women injected with recombinant human relaxin for } \\
28 \text { days, only the subjects demonstrating ovarian cyclicity show } \\
\text { elevated glycodelin in response to recombinant relaxin adminis- } \\
\text { tration, whereas no elevation is seen in placebo-treated subjects or } \\
\text { in the subjects without ovarian cyclicity }\end{array}$ & $(37)$ \\
\hline & $\begin{array}{l}\text { Continuous relaxin administration stimulates glycodelin secretion } \\
\text { throughout the menstrual cycle, including the periovulatory nadir }\end{array}$ & $(37)$ \\
\hline & $\begin{array}{l}\text { In cultured endometrial cells, relaxin increases the glycodelin } \\
\text { production rate two- to six-fold, and the glycodelin mRNA } \\
\text { concentration is increased } 2 \text { - to } 11 \text {-fold }\end{array}$ & $(42)$ \\
\hline Histone deacetylase inhibitors & $\begin{array}{l}\text { SAHA and TSA increase the level of histone acetylation, thereby } \\
\text { turning on glycodelin expression that induces cell growth arrest and } \\
\text { differentiation, attenuated by glycodelin siRNA }\end{array}$ & $(45-47)$ \\
\hline
\end{tabular}

may depend also on factors regulated by progestogen and inhibited by HDAC (48).

\section{Biochemical properties: glycosylation dictates function}

\section{Immunosuppression and apoptosis}

Protection of the human embryo/foetus from maternal immune response is essential for successful reproduction. Glycodelin plays a role here in many ways. After the first report (4), the immunosuppressive nature of glycodelin-A has become well established (Table 3). This is important because decidualised endometrium is replete with immune cells, e.g. lymphocytes, uterine natural killer (NK) cells and monocytes, and the foetal semiallograft is their potential target. Through its actions on T cells, B cells and NK cells glycodelin is involved in foeto-embryonic defence mechanisms (49). Glycodelin is selectively expressed in decidual NK cells (50). It is also found on the sperm head $(26,27,51,52)$.

Table 3 Immunosuppressive effects of glycodelin-A.

\begin{tabular}{ll}
\hline Effect & References \\
\hline $\begin{array}{l}\text { Suppresses lymphocyte proliferation } \\
\text { Induces tolerogenic phenotype in } \\
\text { monocyte-derived dendritic cells }\end{array}$ & $(56)$ \\
$\begin{array}{l}\text { Inhibits T cell activity/proliferation, induces } \\
\text { apoptosis }\end{array}$ & $(57)$ \\
$\begin{array}{l}\text { Inhibits B cell activity/proliferation } \\
\text { Induces apoptosis in monocytes }\end{array}$ & $(53,58,59)$ \\
\hline
\end{tabular}

The sperm-bound glycodelin may protect spermatozoa against maternal lymphocytes by glycosylation-dependent actions (15).

Glycodelin appears to desensitise T-cell receptor (TCR) signalling by its association with the tyrosine phosphatase receptor, CD45 (53). Other mechanisms may also be involved because glycodelin-A is inhibitory to T-cells upon phorbol ester and ionophore stimulation that bypass the TCR-proximal signalling events (54). The $\mathrm{IC}_{50}$ for glycodelin-A activity on T-cells is around $200 \mathrm{nM}(5.6 \mu \mathrm{g} / \mathrm{l})(54)$. This is within the concentration range of glycodelin-A in the first trimester amniotic fluid and decidualised endometrium $(19,25)$. Thus, the glycodelin concentration at the foeto-maternal interface is sufficiently high to contribute to protection of the foetal semiallograft against maternal immune cells, without generalised immunocompromise in pregnant women whose blood concentration of glycodelin is too low to produce detectable immunosuppression $(24,54,55)$.

Apoptosis Glycodelin-A induces apoptosis both in T-cells and monocytes. This activity is caspase-dependent and is related to immunosuppressive activity (59). The effect is glycosylation dependent, which may explain some of the variable results $(54,59,61-64)$. Specially, the terminal sialic acid residues and the size of the glycans appear important. Recombinant glycodelin from Chinese hamster ovary $(\mathrm{CHO})$ cells with the same protein backbone as in glycodelin-A shows no apoptotic activity, but it can be rendered apoptotic by mannosidase treatment (61). This may result from the high proportion of oligomannoside glycans in the proteins 
produced in CHO cells (65) and from the fact that the major complex type $\mathrm{N}$-glycans in glycodelin produced in $\mathrm{CHO}$ cells are devoid of the typical lacdiNAc glycans present in glycodelin-A (66). Accessibility to the apoptotic region of glycodelin may modulate apoptotic activity either by masking or unmasking the functional region in the glycodelin molecule (61).

In peripheral blood $\mathrm{T}$ cells treated with glycodelin-A, mitochondrial depolarisation precedes the onset of DNA fragmentation in apoptosis (54). When a human T-cell leukaemia cell line and its derivative overexpressing antiapoptotic Bcl-2 were treated with glycodelin-A, the Bcl-2 overexpressing cells were resistant to mitochondrial membrane permeabilisation and apoptosis. This indicates that overexpression of $\mathrm{Bcl}-2$ is sufficient to rescue these cells from glycodelin-A induced death (54). In addition to, the NK cell activity in the innate immune system, glycodelin also inhibits proliferation of several monocytic cell lines and induces apoptosis in these cell lines as well as in primary monocytes through caspaseindependent intrinsic mitochondrial pathway (64). These results exemplify the mechanisms by which glycodelin exhibits its apoptotic action. They also suggest that, at the foeto-maternal interface, glycodelin plays a protective role by depleting the monocytes that could become proinflammatory, leaving the macrophages untouched to carry on with efficient clearance of the apoptotic cells (64).

\section{Fertilisation}

Glycodelin regulates sperm function during critical steps of the fertilisation process (Fig. 2). These activities depend on the specific glycosylation patterns of glycodelin that vary in different parts of the reproductive tract. Glycodelin binding to ejaculated spermatozoa is positively correlated with sperm morphology (67). Glycodelin-S binds on the sperm head, thereby inhibiting cholesterol efflux and capacitation of the spermatozoa (52). Glycodelin-S is removed from spermatozoa as they migrate through the uterine cervix to reach the oocyte in the fallopian tube. In the uterine cavity, sperm-bound glycodelin-A protects the spermatozoa against maternal lymphocytes (15).

Fertilisation depends on successful binding of the spermatozoa to the zona pellucida, followed by acrosome reaction. Glycodelin-A inhibits sperm-oocyte binding (6). Therefore, absence or low abundance of glycodelin-A in endometrium during the periovulatory fertile window is biologically meaningful (55). Certain progestin-based contraceptives increase endometrial glycodelin-A secretion over the fertile midcycle (68), possibly contributing to the contraceptive effect.

After ovulation, follicular fluid with the oocytecumulus complex is transported to the oviduct where fertilisation takes place. The spermatozoa have to migrate through the uterus, follicular fluid and eventually the cumulus oophorus in order to bind to the zona pellucida. Follicular fluid glycodelin-F binds to the sperm head and shares the zona-binding inhibitory activity with glycodelin-A $(14,26)$. In addition, glycodelin-F inhibits progesterone-induced acrosome reaction (26). This activity may prevent premature acrosome reaction in the fertilising spermatozoon before it has attached to the zona pellucida.

Both glycodelin-A and -F compete with zona pellucida glycoproteins for receptors on the sperm membrane. The receptor involved in this binding has been identified as fucosyltransferase 5 (FUT5) (70). The receptor binds competitively to both glycodelin-A and the zona pellucida glycoproteins. Therefore, prior binding of glycodelin-A to FUT5 on a spermatozoon may occupy its binding site(s) of the zona pellucida glycoproteins and inhibit fertilisation unless glycodelin$\mathrm{A}$ is transformed or removed (70) (Fig. 2).

The cumulus cells can transform the inhibitory isoforms glycodelin-A and -F to glycodelin-C (27). This glycoform can displace the inhibitory glycoforms from spermatozoa, thereby enhancing their zona-binding capacity. Taken together, the changes in glycodelin glycosylation can provide a powerful posttranslational mechanism to regulate biological activity of glycodelin that affects fertilisation.

\section{Endometrial receptivity and implantation}

Endometrial receptivity is a prerequisite for successful implantation. The receptivity is maximal when the endometrium is in mid-secretory phase, between cycle days 20 and 24 or 6 and 10 days after ovulation. Considering the steep daily rise in glycodelin-A expression during the receptive phase, precise dating of the samples in respect of ovulation (e.g. preovulatory LH surge or hCG administration, or oocyte retrieval) is critical for clinical studies. Glycodelin is abundant in endometrium during the window of implantation (19-21), when the apical membranes lining the uterine cavity develop large membrane projections called pinopodes (71). Glycodelin is localised on the pinopodes, but it is also secreted from luminal epithelial glands regardless of pinopode formation (72). Temporal associations have been found between glycodelin and other markers of endometrial receptivity, such as progestrone receptor B (PRB; inverse correlation), leukaemia inhibitory factor receptor (72), $\alpha v \beta 3$ integrin (vitronectin receptor) (73) and MUC-1 (74), the major cell surface mucin. During implantation, the human blastocyst increases endometrial antiadhesive MUC-1 protein during the apposition phase, whereas it induces paracrine cleavage in MUC- 1 at the implantation site (75). Reduction of MUC1 with increasing glycodelin concentration at the implantation site may have a connection because glycodelin transfection has been found to downregulate MUC-1 expression in endometrial carcinoma cells. The significance of the inverse relationship between glycodelin and MUC-1 in the human implantation remains to be investigated. 
Glycodelin isoforms

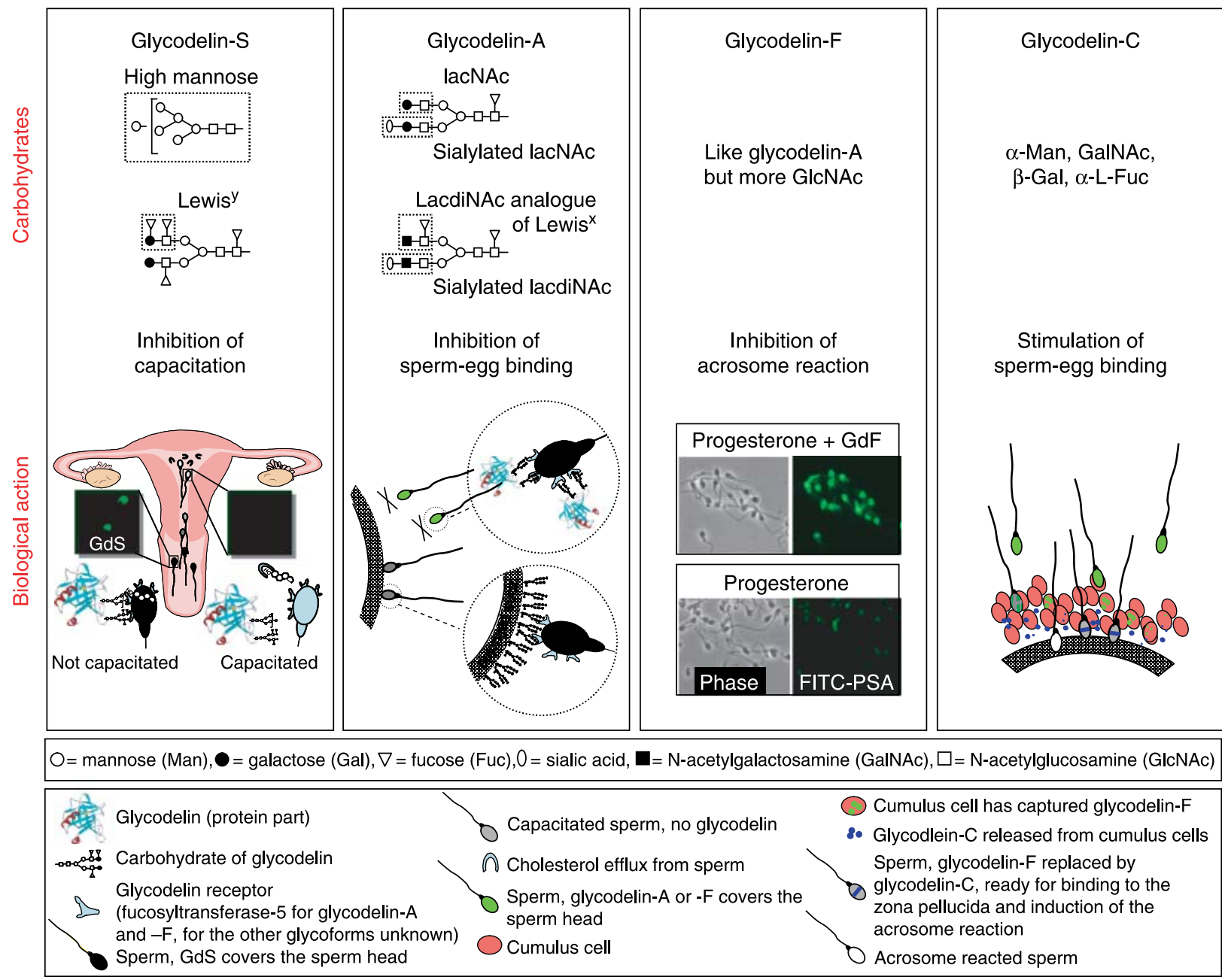

Figure 2 Biological actions of glycodelin isoforms in human fertilisation. Data compiled from data in Refs $(2,3,6,14,15,26,27,52,69,70)$.

In regards to endometrial receptivity following controlled ovarian hyperstimulation $(\mathrm{COH})$, glandular/stromal dyssynchrony is common on cycle day $21-23$ histology, accelerated maturation being more common in the stroma than in the glands (73). Due to variations in treatment modalities and study designs, results on glycodelin serum levels as predictors of implantation have given mixed results $(38,76)$. But, in concordance with the advancement of endometrial maturation morphology, endometrial glycodelin-A expression is significantly increased throughout the implantation phase of the cycles with $\mathrm{COH}$ when compared with normal menstrual cycles (77). Results of microarray profiling of endometrial genes have confirmed the upregulation of glycodelin at the implantation phase (21) but, more than 200 genes showed more than threefold differential gene expression when the biopsies taken at $\mathrm{LH}+7$ of the previous natural cycle were compared with the biopsies taken at hCG +7 of the $\mathrm{COH}$ cycle. The large number of gene expression disturbance highlights the need for efforts to optimise the $\mathrm{COH}$ protocols (78).

Other reasons for variable results arise from technical differences. For instance, some glycodelin peptide antibodies differ from those generated using native glycosylated glycodelin, producing variable results on proliferative versus secretory phase endometrium (15, 79-81). Furthermore, endometrial cells expressing fulllength glycodelin protein have shown upregulation of adhesion ability, whereas those expressing a splicing variant that lacks part of glycodelin encoded by exon 4 have shown downregulation of the same (47). Furthermore, there are ethical constraints to study human implantation directly. Therefore, a step forward is the use of an in vitro implantation assay (47). It employs attachment of choriocarcinoma cells to endometrial adenocarcinoma cells, mimicking trophoblast-to-endometrium attachment in implantation. Here, induction of glycodelin expression in endometrial cells by either steroid hormones or SAHA has been 
found to enhance trophoblast-to-endometrium attachment that can be abrogated by downregulation of the glycodelin gene with siRNA (47). The dramatic effects brought about by glycodelin gene silencing demonstrate the important role glycodelin plays in the trophoblastto-endometrium attachment. The results also suggest that histone deacetylase inhibitors have the potential to supplant steroids in the treatment of implantation failure (47).

\section{Conditions related to implantation and placentation failure}

Unexplained infertility and early pregnancy loss Unexplained infertility or recurrent miscarriage may result from inadequate implantation and/or placentation. In such conditions, subnormal glycodelin concentrations have been reported in endometrium, uterine flushings and serum at the time of expected endometrial receptivity (82-85). Both glycodelin mRNA and protein are downregulated in human first trimester miscarriage (86), and pregnant women with polycystic ovary syndrome (PCOS), who subsequently miscarry show subnormal rise of glycodelin serum concentration during the first trimester, compatible with weaker placentation (87). As women with PCOS may have insulin resistance, it is not surprising that treatment with metformin has been found to increase glycodelin serum concentration in non-pregnant women with PCOS (88). However, in non-pregnant women, hyperinsulinaemic clamp causes only small fluctuations within the normal range of serum glycodelin concentration, demonstrating that insulin has no significant acute effect on serum glycodelin concentration (89).

Endometriosis Here, endometrial tissue is found outside the uterus, and the condition is associated with pelvic pain and infertility. Implantation failure due to progesterone resistance has been suggested to underlie endometriosis-related infertility (90). This is supported by meta-analysis data showing that pregnancy rates from IVF treatment of women with endometriosis and infertility are only $56 \%$ of those in women who undergo IVF treatment for tubal factor infertility (91). Endometriotic lesions are histologically similar to the eutopic endometrium, but they are genetically and biochemically different $(92,93)$. For instance, implantation failure due to endometrial factors is indicated by parallelled gene expression profiling studies using oligonucleotide microarrays that uncover differentially regulated genes in eutopic endometrium from women with versus without endometriosis (92). Among the genes that are upregulated during the normal window of implantation, many genes were significantly decreased in women with endometriosis. These included glycodelin. On the other hand, many other genes that are normally downregulated during the window of implantation were significantly upregulated with endometriosis $(92,93)$. Although epithelial cells of pelvic and ovarian endometriotic implants express glycodelin, its cyclic expression is more irregular than in eutopic endometrium (94). Glycodelin is shed from endometriotic lesions into the peritoneal fluid and/or serum, depending on the type and penetration of the lesions $(95,96)$. In view that peritoneal fluid from women with endometriosis decreases sperm binding to the zona pellucida in hemizona assay (97), glycodelin in peritoneal fluid may contribute to this activity. Significantly, eutopic endometrium from women with and without endometriosis shows biochemical differences in many markers that have $\operatorname{PRE}(\mathrm{s})$ in their promoter region (98). One of these aberrancies is reduced periimplantation phase glycodelin expression in eutopic endometrium, found in women with mild endometriosis. This suggests the presence of endometrial abnormalities that are intrinsic to the disorder rather than a late manifestation $(93,98)$.

\section{Hormone-related cancer}

\section{Breast cancer}

Both oestrogen and progesterone are involved in breast carcinogenesis. Evidence from large studies on postmenopausal hormone replacement therapy shows an increased incidence of breast cancer in women taking combined treatment with $\mathrm{E}$ and P, but not with $\mathrm{E}$ alone (99, 100). The reports have raised concern and criticism because retrospective and observational studies had suggested even protection or no increased risk $(101,102)$. Notwithstanding this, the reports have led to reduction of long-term hormone replacement therapy in postmenopausal women.

In addition to the occurrence of estradiol receptors (ER) and progesterone receptors (PR) in the normal breast and breast cancer tissue, both glycodelin mRNA and protein are expressed. In breast cancer tissue, glycodelin expression has been observed in $69 \%$ of ER/PR-negative and $74 \%$ of the receptor-positive tumours (31). This irrespective, glycodelin expression may be significant because of its relationship with growth restriction and cell differentiation in breast cancer cells in vitro, and the results showing that glycodelin transfection into breast cancer cells can lead to reversion of the malignant phenotype (32). In addition, glycodelin has been shown to reduce breast cancer xenograft growth in vivo (Fig. 3). In hormone-responsive tumours, glycodelin-induced differentiation is related to the decreased expression of oncogenes and an increased expression of tumour suppressor genes, emphasising the tumour suppressor nature of glycodelin (Table 4). The role of glycodelin glycosylation in the transfected tumour cells is still an unresolved issue that may account for the diverse responses in the cell lines studied (104). But interestingly, glycodelin-inducing SAHA has been reported to 
act as a trans-differentitation agent in MCF-7 breast cancer cells (105). Therefore, the recent approval of SAHA by the US Food and Drug Administration for the treatment of malignant cutaneous T-cell lymphoma (106) may be of interest for clinical trials also in breast cancer and endometrial cancer (see below). The significance of glycodelin expression in breast cancer patients is further indicated by clinical results showing that glycodelin expression varies according to the clinical stage: it is detected in $100 \%$ of carcinoma in situ tumours, $90 \%$ of invasive carcinomas without metastases, $50 \%$ of tumours with lymph node metastases, $40 \%$ of those with distant metastases and $38 \%$ of recurrent tumours, suggesting prognostic significance of glycodelin expression in cancer tissue (107).

\section{Endometrial cancer}

Cancer of the endometrium is the most common gynaecologic malignancy that accounts for $6 \%$ of all cancers in women, the incidence rising after 50 years of age. The disease is associated with obesity, hyperinsulinaemia, unopposed oestrogen exposure and hyperandrogenism which are risk factors for endometrial carcinoma. For instance, prolonged exposure to unopposed oestrogen may result in endometrial hyperplasia and eventually carcinoma (108), and progesterone counteracts this development (109). Likewise, prolonged anovulation in women with PCOS may eventually lead to endometrial cancer, not only through unopposed oestrogen, but also through hyperandrogenaemia, hyperinsulinaemia and insulin resistance that are common in this disorder (110). The most common presenting symptom is abnormal uterine bleeding. Endometrial carcinoma may or may not contain ER and PR, and their presence correlates with the FIGO grade and survival. For detailed guidelines of diagnosis, classification and treatment the readers are referred to the FIGO guidelines (111).

In addition to the alterations in the malignant epithelial cells, endometrial cancer is characterised by alterations in the stromal cells and the supporting extracellular matrix. The basement membrane plays an important part in stromal-epithelial interactions.
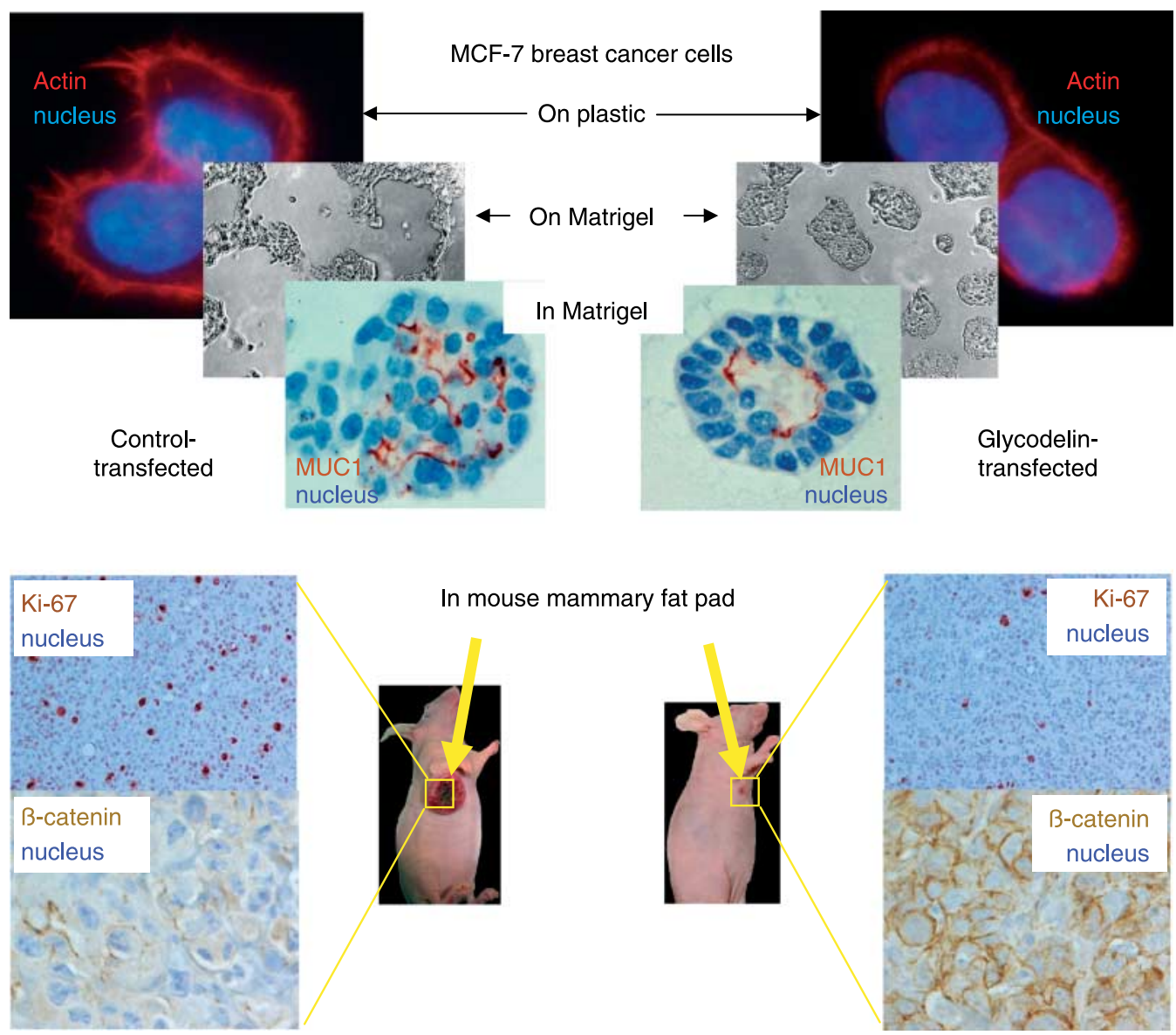

Figure 3 Glycodelin transfected human MCF-7 breast cancer cells show morphologic changes towards the normal phenotype in different growth substrata and reduced xenograft tumour growth associated with reduced expression of Ki-67 cell proliferation marker, and increased $\beta$-catenin, a sign of favourable prognosis (103). Data adapted from Ref. (104). 
Table 4 Glycodelin transfection into hormone related cancer cells regulates expression of genes associated with tumour growth and/or metastasis.

\begin{tabular}{|c|c|c|}
\hline Glycodelin induced changes & Significance $^{a}$ & References \\
\hline \multicolumn{3}{|l|}{ Tumour growth/metastasis promoting genes } \\
\hline Reduces MUC1 and Bcl- $\mathrm{X}_{\mathrm{L}}{ }^{\mathrm{b}}$ & Decreases chemoresistance & (114) \\
\hline Reduces cyclin-dependent kinase $2^{c}$ & Reduces tumour growth & (104) \\
\hline Reduces matrix metalloproteinase $1^{\mathrm{c}}$ & Decreases metastatic propensity & $(104)$ \\
\hline Reduces cyclin D1 ${ }^{\mathrm{d}}$ & Reduces tumour growth & (104) \\
\hline Reduces transglutaminase $2^{\mathrm{d}}$ & Decreases chemoresistance & $(104)$ \\
\hline \multicolumn{3}{|l|}{ Tumour growth/metastasis suppressing genes } \\
\hline Increases caveolin-1 and FGF2 ${ }^{c}$ & Reduces tumour growth & (104) \\
\hline Increases membranous $\beta$-catenin ${ }^{\mathrm{c}, \mathrm{d}}$ & Better prognosis & (104) \\
\hline Increases cyclin dependent kinase inhibitors p21, p27 and p16 & Reduces tumour growth & $(115)$ \\
\hline
\end{tabular}

a Suggested cancer related significance of the observed gene expression changes.

${ }^{b}$ HEC-1B endometrial carcinoma cells.

${ }^{\mathrm{C}} \mathrm{MCF}-7$ breast cancer cells.

${ }^{\mathrm{d}}$ MCF-7 breast cancer xenograft tumours.

e Ishikawa endometrial adenocarcinoma cells.

Whereas glycodelin is a major bioactive protein in the normal secretory endometrium, it has not been detected in endometrial adenocarcinoma tissue (112). But, glycodelin can be induced in endometrial adenocarcinoma cells. At the same time as glycodelin becomes expressed the phenotype of carcinoma cells differentiates to more closely resemble normal endometrial epithelium. This has been achieved by reintroduction of stromal factors and appropriate extracellular matrix components to the carcinoma cell culture (113). Interestingly, $\mathrm{E}$ and $\mathrm{P}$ show little growth effect on Ishikawa carcinoma cells in the absence of stromalinduced factors in conditioned medium, whereas the presence of E- and P-treated stromal medium with basement membrane extract brings about phenotypic reversion and glycodelin expression (113). Of note, overexpression of glycodelin in endometrial adenocarcinoma cells reduces cell proliferation, MUC1 staining, and the antiapoptotic $\mathrm{Bcl}-\mathrm{X}_{\mathrm{L}}$ gene expression (114). A similar effect can be obtained with HDACIs $(46,47)$. Importantly, both the HDACI-induced inhibition of cell growth and differentiation and the HDACI-induced glycodelin expression can be attenuated by glycodelin gene silencing with siRNA. This demonstrates the key role glycodelin plays in these changes $(46,47)$. The results also suggest that, in addition to cancer, HDACI or progesterone induced expression of glycodelin contributes to the suppression of endometrial epithelial growth observed during the secretory phase of the cycle (115). Indeed, overexpression of glycodelin has been found to block G1/S progression in cell proliferation, with concomitant upregulation of CDKIs (115) that are known to inhibit cell cycle progression and retard cell growth (116).

Given that progesterone is involved in endometrial glycodelin secretion and differentiation, one would expect some survival benefit from adjuvant progesterone/progestin treatment of women with endometrial cancer. However, meta-analysis of randomised studies and a subsequent large randomised study have shown that this is not the case $(117,118)$. Therefore, progestin treatment is no longer recommended as an adjuvant therapy for endometrial cancer, but the effects on survival, if any, of glycodelin-inducing HDACIs, e.g. SAHA and TSA remain to be examined.

\section{Ovarian cancer}

Ovarian cancer accounts for $23 \%$ of all gynaecologic cancers and $47 \%$ of all deaths from gynaecologic cancer. The largest number of patients with epithelial ovarian cancer is found in the age group 60-64 years (111). The success of treatment depends on early diagnosis. But, early symptoms are rare and there is no effective screening for early disease. Therefore, ovarian cancer is often advanced when detected for the first time. Risk factors for ovarian cancer are essentially reproductive and genetic in nature. Women with no children are at greater risk, and repeated rupture and repair (ovulation) of the surface epithelium provides an opportunity for genetic aberrations to take place. On the other hand, first pregnancy at an early age, early menopause and the use of oral contraceptives are associated with a lower risk (119).

The best biomarker in the management of epithelial ovarian cancer is CA 125 (120). It is better suited for monitoring of treatment than early detection of disease for the first time. Glycodelin is expressed in the normal ovary $(26,33)$. Glycodelin mRNA and protein have also been found in various types of ovarian tumours, from benign cysts to serous, endometrioid and mesonephric carcinomas, as well as carcinosarcoma $(33,121,122)$. In immunohistochemistry, glycodelin is localised to the cancer cells, but staining of various parts of the tissue varies according to the antibodies used. For instance, glycodelin peptide antibodies show wider immunoreactivity extending into vascular endothelium $(79,123)$ compared with the antibodies against native glycosylated glycodelin that show no vascular or angiogenic connection $(15,38,122)$. Moreover, antibodies against 
Table 5 Five- and 10-year overall survival rates of patients with glycodelin-positive and -negative ovarian serous carcinoma.

\begin{tabular}{lccc}
\hline Subjects & $\boldsymbol{n}$ & $\begin{array}{c}\text { 5-year overall } \\
\text { survival (\%) }\end{array}$ & $\begin{array}{c}\text { 10-year } \\
\text { overall } \\
\text { survival (\%) }\end{array}$ \\
\hline All & 460 & 50 & 40 \\
Gd +ve & 301 & $55^{*}$ & $47^{\dagger}$ \\
Gd -ve & 159 & $39^{*}$ & $26^{\dagger}$ \\
\hline
\end{tabular}

${ }^{*} P<0.001,{ }^{\dagger} P<0.0001$. Adapted from Ref. (122).

native glycosylated glycodelin show more frequent expression in well differentiated than in poorly differentiated ovarian serous carcinomas, and it is more common in early stage compared with advanced-stage carcinomas (122). Importantly, the difference remains within the patients of the same grade and the same clinical stage. This was related to survival so that the patients with glycodelin-expressing tumours showed a higher 5- and 10-year overall survival compared with those with glycodelin-negative tumours (Table 5). These results corroborate the findings that glycodelin expression in tumour tissue indicates a favourable prognostic sign, likely due to its differentiation-related actions.

\section{Concluding remarks}

Glycodelin provides a well-documented example of the role protein glycosylation plays in human reproduction and immune cell reactivity. The biological actions depending on the carbohydrate moieties of glycodelin isoforms show that the recognition systems between the gametes and the immune cells have converged - they are both based on similar oligosaccharide structures attached to the same protein backbone. While much of the details still remain uncovered, the key role of glycosylation for biological actions has become even more obvious in view that the unique N-glycans alone, derived from glycodelin-A, can modulate hormone production in trophoblast tumour cells (124). The differentiation-inducing propensity of glycodelin is associated not only with restriction of cell growth and reversion of the malignant phenotype in vitro, but it also has a connection with clinical oncology - glycodelin expression in tumour tissue is a sign of better prognosis. Finally, the studies employing downregulation of glycodelin by siRNA have shown that glycodelin is actually the molecule by which HDACIs execute the differentiation- and cell attachment-enhancing actions. As a HDACI (SAHA) was recently approved by FDA for treatment of a malignant disease, research expanding this propensity into treatment of the hormone-related cancers remains a challenge for future studies.

\section{Declaration of interest}

The authors declare that there is no conflict of interest that prejudice the impartiality of this scientific work.

\section{Funding}

This work was supported by grants from the Helsinki University Central Hospital Research Fund and the Research Grant Council, Hong Kong (HKU 7514/05M and HKU 7647/06M).

\section{References}

1 Julkunen M, Seppälä M \& Jänne OA. Complete amino acid sequence of human placental protein 14: a progestone-regulated uterine protein homologous to B-lactoglobulins. PNAS $1988 \mathbf{8 5}$ 8845-8849.

2 Dell A, Morris HR, Easton R, Panico M, Patankar M, Oehninger S, Koistinen R, Koistinen H, Seppälä M \& Clark GF. Structural analysis of the oligosaccharides derived from glycodelin, a human glycoprotein with potent immunosuppressive and contraceptive activities. Journal of Biological Chemistry $1995 \mathbf{2 7 0}$ 24116-24126.

3 Morris HR, Dell A, Easton RL, Panico M, Koistinen H, Koistinen R, Oehninger S, Patankar MS, Seppälä M \& Clark GE. Gender specific glycosylation of human glycodelin dictates contraceptive activity. Journal of Biological Chemistry 1996271 32159-32167.

4 Bolton AE, Pockley AG, Clough KJ, Mowles EA, Stoker RJ, Westwood OMR \& Chapman MG. Identification of placental protein 14 as an immunosuppressive factor in human reproduction. Lancet 19871 593-595.

5 Okamoto N, Uchida A, Takakura K, Kariya Y, Kanzaki H, Riittinen L, Koistinen R, Seppälä M \& Mori T. Suppression by human placental protein 14 of natural killer cell activity. American Journal of Reproductive Immunology 199126 137-142.

6 Oehninger S, Coddington CC, Hodgen GD \& Seppälä M. Factors affecting fertilization: endometrial placental protein 14 reduces the capacity of human spermatozoa to bind to the human zona pellucida. Fertility and Sterility 199563 377-383.

7 Seppälä M \& Tiitinen A. Endometrial responses to corpus luteum products in cycles with induced ovulation: theoretical and practical considerations. Human Reproduction 199510 67-76.

8 Seppälä M, Bohn H \& Tatarinov Y. Glycodelins. Tumor Biology $199819213-220$.

9 Kämäräinen M, Julkunen M \& Seppälä M. HinfI polymorphism in the human progesterone associated endometrial protein (PAEP) gene. Nucleic Acids Research 1991195092.

10 Chiu PCN, Koistinen R, Koistinen H, Seppälä M, Lee KF \& Yeung WSB. Zona binding inhibitory factor- 1 from human follicular fluid is an isoform of glycodelin. Biology of Reproduction $200369365-372$.

11 Bell SC \& Bohn H. Immunohistochemical and biochemical relationship between human pregnancy-associated secreted endometrial alpha 1- and alpha 2-globulins (alpha 1- and alpha 2-PEG) and the soluble placental proteins 12 and 14 (PP12 and PP14). Placenta $19867283-294$.

12 Julkunen M, Raikar RS, Joshi SG, Bohn H \& Seppälä M. Placental protein 14 and progestagen-dependent endometrial protein are immunologically indistinguishable. Human Reproduction 19861 $7-8$.

13 Vaisse C, Atger M, Potier B \& Milgrom E. Human placental protein 14 gene: sequence and characterization of a short duplication. DNA and Cell Biology 19909 401-413.

14 Yeung WSB, Lee K-F, Koistinen R, Koistinen H, Seppälä M \& Chiu PCN. Roles of glycodelin in modulating sperm function. Molecular and Cellular Endocrinology 2006250 149-156. 
15 Seppälä M, Koistinen H, Koistinen R, Chiu PC \& Yeung WS. Glycosylation related actions of glycodelin: gamete, cumulus cell, immune cell and clinical associations. Human Reproduction Update $200713275-287$.

16 Julkunen M, Wahlström T, Seppälä M, Koistinen R, Koskimies AI, Stenman UH \& Bohn H. Detection and localization of placental protein 14-like protein in human seminal plasma and in the male genital tract. Archives of Andrology 198412 59-67.

17 Koistinen H, Koistinen R, Dell A, Morris HR, Easton RL, Patankar MS, Oehninger S, Clark GF \& Seppälä M. Glycodelin from seminal plasma is a differentially glycosylated form of contraceptive glycodelin-A. Molecular Human Reproduction 1996 2 759-765.

18 Koistinen H, Koistinen R, Kämäräinen M, Salo J \& Seppälä M. Multiple forms of messenger ribonucleic acid encoding glycodelin in male genital tract. Laboratory Investigation 1997 76 683-690.

19 Julkunen M, Koistinen R, Sjöberg J, Ruta-nen EM, Wahlström T \& Seppälä M. Secretory endometrium synthesizes placental protein 14. Endocrinology 1986118 1782-1786.

20 Julkunen M, Koistinen R, Suikkari AM, Seppälä M \& Jänne OA. Identification by hybridization histochemistry of human endometrial cells expressing mRNAs encoding a uterine ß-lactoglobulin homologue and insulin-like growth factor-binding protein-1. Molecular Endocrinology 19904 700-707.

21 Kao LC, Tulac S, Lobo S, Imani B, Yang JP, Germeyer A, Osteen K, Taylor RN, Lessey BA \& Giudice LC. Global gene profiling in human endometrium during the window of implantation. Endocrinology 2002143 2119-2138.

22 Kämäräinen M, Leivo I, Julkunen M \& Seppälä M. Localization of progesterone-associated endometrial protein mRNA by in-situ hybridisation in human pregnancy deciduas, endometriosis and borderline endometrioid adenoma. Journal of Molecular Endocrinology $19931071-77$.

23 Li TC, Dalton C, Hunjan KS, Warren MA \& Bolton AE. The correlation of placental protein 14 concentrations in uterine flushing and endometrial morphology in the peri-implantation period. Human Reproduction 19938 1923-1927.

24 Julkunen M, Rutanen EM, Koskimies AI, Ranta T, Bohn H \& Seppälä M. Distribution of placental protein 14 in tissues and body fluids during pregnancy. British Journal of Obstetrics and Gynaecology 198592 1145-1151.

25 Riittinen L, Julkunen M, Seppälä M, Koistinen R \& Huhtala ML. Purification and characterization of endometrial protein PP14 from mid-trimester amniotic fluid. Clinica Chimica Acta 1989184 19-30.

26 Tse JYM, Chiu PCN, Lee KF, Seppala M, Koistinen H, Koistinen R, Yao YQ \& Yeung WSB. The synthesis and fate of glycodelin in human ovary during folliculogenesis. Molecular Human Reproduction $20028142-148$.

27 Chiu PCN, Chung M-K, Koistinen R, Koistinen H, Seppälä M, Ho PC, Ng EHY, Lee KF \& Yeung WSB. Cumulus oophorusassociated glycodelin-C displaces sperm bound glycodelin-A and $\mathrm{F}$ and stimulates spermatozoa-zona pellucida binding. Journal of Biological Chemistry 2007282 5378-5388.

28 Julkunen M, Wahlström T \& Seppälä M. Human fallopian tube contains placental protein 14. American Journal of Obstetrics and Gynecology 1986154 1076-1079.

29 Laird SM, Hill CJ, Warren MA, Tuckerman EM \& Li TC. The production of placental protein 14 by human uterine tubal epithelial cells in culture. Human Reproduction $1995 \mathbf{1 0}$ 1346-1351.

30 Maguiness SD, Shrimanker K, Djahanbakhch O, Deeks JJ, Teisner B \& Grudzinskas JG. In vitro synthesis of total protein and placental protein 14 by the fallopian tube mucosa: variation in relation to anatomical site, the ovarian cycle and the menopause. Human Reproduction 19938 678-683.

31 Kämäräinen M, Halttunen M, Koistinen R, Boguslawsky von K, Smitten von K, Andersson LC \& Seppälä M. Expression of glycodelin in human breast and breast cancer. International Journal of Cancer 199983 738-742.
32 Kämäräinen $M$, Seppälä $M$, Virtanen I \& Andersson LC. Expression of glycodelin in MCF-7 breast cancer cells induces epithelial differentiation into organized acinar epithelium. Laboratory Investigation 199777 565-573.

33 Kämäräinen M, Leivo I, Koistinen R, Julkunen M, Karvonen U, Rutanen EM \& Seppälä M. Normal human ovary and ovarian tumors express glycodelin, a glycoprotein with immunosuppressive and contraceptive properties. Evidence from immunohistochemical staining and in situ hybridization. American Journal of Pathology 1996148 1435-1443.

34 Morrow DM, Xiong N, Getty RR, Ratajczak MZ, Morgan D, Seppälä M, Riittinen L, Gewirtz AM \& Tykocinski ML. Hematopoietic placental protein 14. An immunosuppressive factor in cells of the megakaryocytic lineage. American Journal of Pathology $19941451485-1495$.

35 Kämäräinen $M$, Riittinen L, Seppälä $M$, Palotie A \& Andersson LC. Progesterone-associated endometrial protein - a constitutive marker of human erythroid precursors. Blood 1994 84 467-473.

36 Julkunen M, Apter D, Seppälä M, Stenman UH \& Bohn H. Serum levels of placental protein 14 reflect ovulation in nonconceptional menstrual cycles. Fertility and Sterility $1986 \mathbf{4 5} 47-50$.

37 Stewart DR, Erikson MS, Erikson ME, Nakajima ST, Overstreet JW, Lasley BL, Amento EP \& Seppälä M. The role of relaxin in glycodelin secretion. Journal of Clinical Endocrinology and Metabolism 199782 839-846.

38 Seppälä M, Taylor RN, Koistinen H, Koistinen R \& Milgrom E. Glycodelin: a major lipocalin protein of the reproductive axis with diverse actions in cell recognition and differentiation. Endocrine Reviews 200223 401-430.

39 Critchley HO, Chard T, Olajide F, Davies MC, Hughes S, Wang HS, Lieberman BA \& Anderson DC. Role of the ovary in the synthesis of placental protein-14. Journal of Clinical Endocrinology and Metabolism 199275 97-100.

40 Reshef E, Lei ZM, Rao CV, Pridham DD, Chegini N \& Luborsky JL. The presence of gonadotropin receptors in nonpregnant human uterus, human placenta, fetal membranes, and decidua. Journal of Clinical Endocrinology and Metabolism 199070 421-430.

41 Fazleabas AT, Donnelly KM, Srinivasan S, Fortman JD \& Miller JB. Modulation of the baboon (Papio anubis) uterine endometrium by chorionic gonadotropin during the period of uterine receptivity. PNAS $1999962543-2548$.

42 Tseng L, Zhu HH, Mazella J, Koistinen H \& Seppälä M. Relaxin stimulates glycodelin mRNA and protein concentrations in human endometrial glandular epithelial cells. Molecular Human Reproduction $19995372-375$.

43 Taylor RN, Savouret J-F, Vaisse C, Vigne J-L, Ryan I, Hornung D, Seppälä M \& Milgrom E. Promegestone (R5020) and mifepristone (RU486) both function as progestational agonists of human glycodelin gene expression in isolated human epithelial cells. Journal of Clinical Endocrinology and Metabolism $1998 \mathbf{8 3}$ 4006-4012.

44 Gao J, Mazella J, Seppala M \& Tseng L. Ligand activated HPR modulates the glycodelin promoter activity through the Sp1 sites in human endometrial adenocarcinoma cells. Molecular and Cellular Endocrinology 2001176 97-102.

45 Bolden JE, Peart MJ \& Johnstone RW. Anticancer activities of histone deacetylase inhibitors. Nature Reviews. Drug Discovery 20065 769-784.

46 Uchida H, Maruyama T, Nagashima T, Asada H \& Yoshimura Y. Histone deacetylase inhibitors induce differentiation of human endometrial adenocarcinoma cells through up-regulation of glycodelin. Endocrinology 2005146 5365-5373.

47 Uchida H, Maruyama T, Ohta K, Ono M, Arase T, Kagami M, Oda H, Kajitani T, Asada H \& Yoshimura Y. Histone deacetylase inhibitor-induced glycodelin enhances the initial step of implantation. Human Reproduction 200722 2615-2622.

48 Jaffe RC, Ferguson-Gottschall SD, Gao W, Beam C \& Fazleabas AT. Histone deacetylase inhibition and progesterone act synergistically to stimulate baboon glycodelin gene expression. Journal of Molecular Endocrinology $2007 \mathbf{3 8}$ 401-407. 
49 Clark GF, Oehninger S, Patankar MS, Koistinen R, Dell A, Morris HR, Koistinen H \& Seppälä M. A role for glycoconjugates in human development: the human feto-embryonic defense system hypothesis. Human Reproduction 199611 467-473.

50 Koopman LA, Kopcow HD, Rybalov B, Boyson JE, Orange JS, Schatz F, Masch R, Lockwood CJ, Schachter AD, Park PJ \& Strominger JL. Human decidual natural killer cells are a unique NK cell subset with immunomodulatory potential. Journal of Experimental Medicine 2003198 1201-1212.

51 Chiu PCN, Koistinen R, Koistinen H, Seppälä M, Lee KF \& Yeung WSB. Binding of zona binding inhibitory factor-1 (ZIF-1) from human follicular fluid on spermatozoa. Journal of Biological Chemistry 2003278 13570-13577.

52 Chiu PCN, Tsang HY, Chung MK, Koistinen R, Koistinen H, Seppälä M, Lee KF \& Yeung WSB. Glycodelin-S in human seminal plasma reduces cholesterol efflux and capacitation of spermatozoa. Journal of Biological Chemistry $200528025580-25589$.

53 Rachmilewitz J, Borovsky Z, Riely GJ, Miller M \& Tykocinski ML. Negative regulation of T cell activation by placental protein 14 is mediated by the tyrosine phosphatase receptor CD45. Journal of Biological Chemistry 2003278 14059-14065.

54 SundarRaj S, Mukhopadhyay D \& Karande AA. Glycodelin A triggers mitochondrial stress and apoptosis in $\mathrm{T}$ cells by a mechanism distinct and independent of TCR signalling. Molecular Immunology 200845 2391-2400.

55 Seppälä M, Koistinen H, Koistinen R, Dell A, Morris HR, Oehninger S \& Clark GF. Glycodelins as regulators of early events of reproduction. Clinical Endocrinology $1997 \mathbf{4 6} 381-386$.

56 Rachmilewitz J, Riely GJ \& Tykocinski ML. Placental protein 14 functions as a direct T-cell inhibitor. Cellular Immunology 1999 $19126-33$.

57 Okamoto N, Uchida A, Takakura K, Kariya Y, Kanzaki H, Riittinen L, Koistinen R, Seppälä M \& Mori T. Suppression by human placental protein 14 of natural killer cell activity. American Journal of Reproductive Immunology 199126 137-142.

58 Mukhopadhyay D, Sundereshan S, Rao C \& Karande AA. Placental protein 14 (PP14) induces apoptosis in T cells, but not in monocytes. Journal of Biological Chemistry $20012 \mathbf{2 7 6}$ 28268-28273.

59 Mukhopadhyay D, SundarRaj S, Alok A \& Karande AA. Glycodelin-A, not glycodelin-S, is apoptotically active. Relevance of sialic acid modification. Journal of Biological Chemistry 2004 279 8577-8584.

60 Yaniv E, Borovsky Z, Mishan-Eisenberg G \& Rachmilewitz J. Placental protein 14 regulates selective B cell responses. Cellular Immunology 2003222 156-163.

61 Jayachandran R, Radcliffe CM, Royle L, Harvey DJ, Dwek RA, Rudd PM \& Karande AA. Oligosaccharides modulate apoptotic activity of glycodelin. Glycobiology $2006 \mathbf{1 6} 1052-1063$.

62 Poornima BL \& Karande AA. Differential sialylation regulates the apoptotic activity of glycodelin A. FEBS Letters $2007 \mathbf{5 8 1}$ 4366-4370.

63 Tee MK, Vigne JL, Yu J \& Taylor RN. Natural and recombinant human glycodelin activates a proapoptitic gene cascade in monocyte cells. Journal of Leukocyte Biology $2008 \mathbf{8 3} 843-852$.

64 Alok A, Mukhopadhyay D \& Karande AA. Glycodelin A, an immunomodulatory protein in the endometrium, inhibits proliferation and induces apoptosis in monocytic cells. International Journal of Biochemistry and Cell Biology, 2008 (Epub ahead of print).

65 Matsuura F, Ohta M, Ionnou YA \& Desnick RJ. Human alphagalactosidase A: characterization of the N-linked oligosaccharides on the intracellular and secreted glycoforms overexpressed by Chinese hamster ovary cells. Glycobiology $1998 \mathbf{8} 329-339$.

66 Van den Nieuwenhof IM, Koistinen H, Easton RL, Koistinen R, Kämäräinen M, Morris HR, vanDie I, Seppälä M, Dell A, VanDenEijnden DH, Kämäräinen M, Morris HR, van Die I, Seppälä M, Dell A \& Van Den Eijnden DH. Recombinant glycodelin carrying the same type of glycan structures as contraceptive glycodelin-A can be produced in human kidney 293 cells but not in Chinese hamster ovary cells. European Journal of Biochemistry 2000267 4753-4762.

67 Gneist N, Keck G, Zimmermann A, Trinkaus I, Kuhlisch E \& Distler W. Glycodelin binding to human ejaculated spermaatozoa is correlated with sperm morphology. Fertility and Sterility 2007 88 1358-1365.

68 Mandelin E, Koistinen H, Koistinen R, Affandi B \& Seppälä M. Levonorgestrel-releasing IUD-wearing women express contraceptive glycodelin-A in endometrium during midcycle: another contraceptive mechanism? Human Reproduction 199712 2671-2675.

69 Koistinen H, Koistinen R, Seppälä M, Burova TV, Choiset Y \& Hærtlé T. Glycodelin and B-lactoglobulin, lipocalins with high structural similarity, differ in ligand binding properties. FEBS Letters $1999450158-162$.

70 Chiu PCN, Chung M-K, Koistinen R, Koistinen H, Seppälä M, Lee KF, Ho PC, Ng EH \& Yeung WSB. Glycodelin-A interacts with fucosyltransferase on human sperm plasma membrane to inhibit spermatozoa-zona pellucida binding. Journal of Cell Science 2007 $12033-44$.

71 Nikas G. Endometrial receptivity: changes in cell-surface morphology. Seminars in Reproductive Medicine 200018 229-235.

72 Stavreus-Evers A, Mandelin E, Koistinen R, Aghajnova L, Hovatta O \& Seppälä M. Glycodelin is present in pinopodes of receptive phase human endometrium, and its presence is associated with downregulation of progesterone receptor B. Fertility and Sterility $2006 \mathbf{8 5} 1803-1811$.

73 Damario MA, Lesnick TG, Lessey BA, Kowalik A, Mandelin E, Seppälä M \& Rosenwaks Z. Endometrial markers of uterine receptivity utilizing the donor oocyte model. Human Reproduction 200116 1893-1899.

74 Aplin J, Self M, Graham R, Hey NA, Behzad F \& Campbell S. The endometrial cell surface and implantation. Expression of polymorphic mucin (MUC-1) and adhesion molecules during the endometrial cycle. Annals of the New York Academy of Sciences 1994734 103-121.

75 Meseguer M, Aplin J, Caballero-Campo P, O'Connor JE, Martin JC, Remohi J, Pellicer A \& Simón C. Human endometrial mucin MUC1 is up-regulated by progesterone and down-regulated in vitro by the human blastocyst. Biology of Reproduction $2001 \mathbf{6 4}$ 590-601.

76 Westergaard LG, Wiberg N, Andersen CY, Laursen SB, Kliem A, Westergaard JG \& Teisner B. Circulating concentrations of placenta protein 14 during the natural menstrual cycle in women significantly reflect endometrial receptivity to implantation and pregnancy during successive assisted reproduction cycles. Human Reproduction 199813 2612-2619.

77 Brown SE, Mandelin E, Oehninger S, Toner JP, Seppala M \& Jones HW Jr. Endometrial glycodelin A expression in the liteal phase of stimulated ovarian cycles. Fertility and Sterility $2000 \mathbf{7 4}$ 130-133.

78 Horcajadas JA, Riesewijk A, Polman J, van Os R, Pellicer A, Mosselman S \& Simon C. Effect of controlled ovarian hyperstimulation in IVF on endometrial gene expression profiles. Molecular Human Reproduction 200511 195-205.

79 Horowitz IR, Cho CH, Song MQ, Flowers LC, Santanam N, Parthasarathy S \& Ramachandran S. Increased glycodelin levels in glycecological malignancies. International Journal of Gynecological Cancer 200111 173-179.

80 Poddar AS, Kim JG, Gill KP, Bates BN, Santanam N, Rock JA, Murphy AA \& Parthasarathy S. Generation and characterization of a polyclonal antipeptide antibody to human glycodelin. Fertility and Sterility $1998 \mathbf{6 9} 543-548$.

81 Mylonas I, Jeschke U, Kunert-Keil C, Shabani N, Dian D, Bauerfeind I, Kuhn C, Kupka MS \& Friese K. Glycodelin A is expressed differentially in normal human endometrial tissue throughout the menstrual cycle by immunohistochemistry and in situ hybridization. Fertility and Sterility $2006 \mathbf{8 6} 1488-1497$. 
82 Mackenna A, Li TC, Dalton C, Bolton A \& Cooke I. Placental protein 14 levels in uterine flushing and plasma of women with unexplained infertility. Fertility and Sterility 199359 577-582.

83 Klentzeris LD, Bulmer JN, Seppälä M, Li TC, Warren MA \& Cooke ID. Placental protein 14 in cycles with normal and retarded endometrial differentiation. Human Reproduction 19949 394-398.

84 Dalton CF, Laird SM, Estdale SE, Saravelos HG \& Li TC. Endometrial protein PP14 and CA-125 in recurrent miscarriage patients: correlation with pregnancy outcome. Human Reproduction 199813 3197-3202.

85 Tulppala M, Julkunen M, Tiitinen A, Stenman U-H \& Seppälä M. Habitual abortion is accompanied by low serum levels of placental protein 14 in the luteal phase of the fertile cycle. Fertility and Sterility $199563792-795$.

86 Toth B, Roth K, Kunert-Keil C, Scholz C, Schulze S, Mylonas I, Friese K \& Jeschke U. Glycodelin protein and mRNA is downregulated in human first trimester abortion and partially upregulated in mole pregnancy. Journal of Histochemistry and Cytochemistry $2008 \mathbf{5 6}$ 477-485.

87 Jakubowicz DJ, Essah PA, Seppala M, Jakubowicz S, Koistinen R \& Nestler JE. Reduced glycodelin and insulin-like growth factorbinding protein-1 in women with polycystic ovary syndrome during first trimester of pregnancy. Journal of Clinical Endocrinology and Metabolism 200489 833-839.

88 Jakubowicz DJ, Seppälä M, Jakubowicz S, Rodriguez-Armas O, Rivas-Santiago A, Koistinen H, Koistinen R \& Nestler JE. Insulin reduction with metformin increases luteal-phase serum glycodelin and insulin-like growth factor binding protein 1 concentrations and enhances uterine vascularity and blood flow in the polycystic ovary syndrome. Journal of Clinical Endocrinology and Metabolism 200186 1126-1133.

89 Seppälä M, Mandelin E, Koistinen R, Bergholm R, Tiikkainen M \& Yki-Järvinen $\mathrm{H}$. Glycodelin responses to hyperinsulinaemic clamp vary according to basal glycodelin concentration. Clinical Endocrinology 200562 611-615.

90 Attia GR, Zeltoun K, Edwards D, Johns A, Carr BR \& Bulun SE. Progesterone receptor isoform A but not B is expressed in endometriosis. Journal of Clinical Endocrinology and Metabolism 200085 2897-2902.

91 Barnhart K, Dunsmoor-Su R \& Coutifaris C. Effect of endometriosis on in vitro fertilization. Fertility and Sterility $2002 \mathbf{7 7}$ 1148-1155.

92 Kao LC, Germeyer A, Tulac S, Lobo S, Yang JP, Taylor RN, Osteen K, Lessey BA \& Giudice LC. Expression profiling of endometrium from women with endometriosis reveals candidate genes for disease-based implantation failure and infertility. Endocrinology $2003 \mathbf{1 4 4} 2870-2981$.

93 Meola J, Dentillo DB, Silva RE, Ferriani RA, Veiga LC, Paro de Paz CC \& Martelli L. Glycodelin expression in the endometrium of healthy women and in the eutopic and ectopic endometrium of women with endometriosis. Fertility and Sterility, 2008 (Epub ahead of print).

94 Cornillie FJ, Lauweryns JM, Seppälä M, Riittinen L \& Koninckx PR. Expression of endometrial protein PP14 in pelvic and ovarian endometriotic implants. Human Reproduction 1991 10 1411-1415.

95 Telimaa S, Kauppila A, Rönnberg L, Suikkari A-M \& Seppälä M. Elevated serum levels of endometrial secretory protein PP14 in patients with advanced endometriosis. Suppression by treatment with danazol and high-dose medroxyprogesterone acetate. American Journal of Obstetrics and Gynecology 1989161 866-871.

96 Koninckx PR, Riittinen L, Seppälä M \& Cornillie FJ. CA-125 and placen-tal protein 14 concentrations in plasma and peritoneal fluid of women with deeply in-filtrating pelvic endometriosis. Fertility and Sterility $1992 \mathbf{5 7} 523-530$.

97 Coddington CC, Oehninger S, Cunningham DS, Hansen K, Sueldo C \& Hodgen GD. Peritoneal fluid from patients with endometriosis decreases sperm binding to the zona pellucida in the hemizona assay: a preliminary report. Fertility and Sterility 199257 783-786.

98 Wei Q, St Clair JB, Fu T, Stratton P \& Nieman LK. Reduced expression of biomarkers associated with the implantation window in women with endometriosis. Fertility and Sterility, 2008 (Epub ahead of print).

99 Chlebowski RT, Hendrix SL, Langer RD, Stefanick ML, Gass M, Lane D, Rodabough RJ, Gillian MA, Cyr MG, Thomson CA, Khandekar J, Petrovich H, McTiernan A \& WHI Investigators. Influence of estrogen plus progestin on breast cancer and mammography in healthy postmenopausal women: the Women's Health Initiative randomised trial. Journal of the American Medical Association 2003289 3243-3253.

100 Stefanick ML, Anderson GL, Margolis KL, Hendrix SL, Rodabough RJ, Paskett ED, Lane DS, Hubbell FA, Assaf AR, Sarto GE, Schenken RS, Yasmeen S, Lessin L, Chlebowski RT \& WHI Investigators. Effects of conjugated equine estrogens on breast cancer and mammography screening in postmenopausal womenn with hysterectomy. Journal of the American Medical Association 2006295 1647-1657.

101 Speroff L. A clinicians review of the WHI-related literature. International Journal of Fertility and Women's Medicine 200449 252-267.

102 Creasman WT. Breast cancer: the role of hormone therapy. Seminars in Reproductive Medicine 200523 167-171.

103 Dolled-Filhart M, McCabe A, Giltnane J, Cregger M, Camp RL \& Rimm DL. Quantitative in situ analysis of $\beta$-catenin expression in breast cancer shows decreased expression is associated with poor outcome. Cancer Research 200666 5487-5494.

104 Hautala L, Koistinen R, Seppälä M, Bützow R, Stenman UH, Laakkonen P \& Koistinen H. Glycodelin reduces breast cancer xenograft growth in vivo. International Journal of Cancer 2008 123 2279-2284.

105 Munster PN, Troso-Sandoval T, Rosen N, Rifkind R, Marks PA \& Richon VM. The histone deacetylase inhibitor suberoylanilide hydroxamic acid induces differentiation of human breast cancer cells. Cancer Research $2001618492-8497$.

106 Mann BS, Johnson JR, Cohen MH, Justice R \& Pazdur R. FDA approval summary: vorinostat for treatment of advanced primary cutaneous T-cell lymphoma. Oncologist $2007 \mathbf{1 2}$ 1247-1252.

107 Jeschke U, Mylonas I, Kunert-Keil C, Dazert E, Shabani N, Werling M, Kuhn C, Janni W, Gerber B \& Friese K. Expression of glycodelin protein and mRNA in human ductal breast cancer carcinoma in situ, invasive ductal carcinomas, their lymph node and distant metastases, and ductal carcinomas with recurrence. Oncology Reports 200513 413-419.

108 Ziel HK \& Finke WD. Increased risk of endometrial carcinoma among users of conjugated estrogens. New England Journal of Medicine $19752931167-1170$.

109 Jick SS, Walker AM \& Jick H. Estrogens, progesterone, and endometrial cancer. Epidemiology 19934 20-24.

110 Navaratnarajah R, Pillay OC \& Hardiman P. Polycystic ovary syndrome and endometrial cancer. Seminars in Reproductive Medicine 200826 62-71.

111 Benedet JL, Bender H, Jones H III, Ngan HY \& Pecorelli S. FigO staging classifications and clinical practice guidelines in the management of gynaecologic cancers. FigO Committee of Gynecologic Oncology. International Journal of Gynecology and Obstetrics 200070 209-262.

112 Chatzaki E, Gallaher CJ, Iles RK, Ind TE, Nouri AM, Bax CM \& Grudzinskas JG. Characterisation of the differential expression of marker antigens by normal and malignant endometrial epithelium. British Journal of Cancer 199469 1010-1014.

113 Arnold JT, Lessey BA, Seppala M \& Kaufman DG. Effect of normal endometrial stroma on growth and differentiation in Ishikawa endometrial adenocarcinoma cells. Cancer Research $20026279-88$. 
114 Koistinen H, Seppälä M, Nagy B, Tapper J, Knuutila J \& Koistinen R. Glycodelin reduces carcinoma-associated gene expression in endometrial adenocarcinoma cells. American Journal of Obstetrics and Gynecology 2005193 1955-1960.

115 Ohta K, Maruyama T, Uchida H, Ono M, Nagashima T, Arase T, Kajitani T, Oda H, Morita M \& Yoshimura Y. Glycodelin blocks progression to $S$ phase and inhibits cell growth: a possible progesterone-induced regulator for endometrial epithelial cell growth. Molecular Human Reproduction 200814 17-22.

116 Shapiro GI. Cyclin-dependent kinase pathways as targets for cancer treatment. Journal of Clinical Oncology $2006 \mathbf{2 4} 1770-1783$.

117 Martin-Hirsch PL, Lilford RJ \& Jarvis GJ. Adjuvant progestagen therapy for the treatment of endometrial cancer: review and meta-analyses of published randomised controlled trials. European Journal of Obstetrics, Gynecology, and Reproductive Biology 199665 201-207.

118 COSA-NZ-UK Endometrial Cancer Study Groups. Adjuvant medroxyprogesterone acetate in high-risk endometrial cancer. International Journal of Gynecological Cancer 19988 387-391.

119 DiSaia P \& Creasman W. Epithelial ovarian cancer. Clinical Gynecologic Oncology, 6th edn, pp 289-350. Mosby, 2002.

120 Bast RC Jr, Krug TL, Schaetzl E, Lavin P, Niloff JM, Greber TF, Zurawski VR Jr \& Knapp RC. Monitoring human ovarian carcinoma with a combination of CA 125, CA 19-9, and carcinoembryonic antigen. American Journal of Obstetrics and Gynecology 1984149 553-559.

121 Riittinen L. Serous ovarian cyst fluids contain high levels of endometrial placental protein 14. Tumor Biology 199213 175-179.

122 Mandelin E, Lassus H, Seppälä M, Leminen A, Gustafsson J-Å, Cheng G, Butzow R \& Koistinen R. Glycodelin in ovarian serous carcinoma: association with differentiation and survival. Cancer Research 200363 6258-6264.

123 Song M, Ramaswamy S, Ramachandran S, Flowers LC, Horowiz IR, Rock JA \& Parthasarathy S. Angiogenic role for glycodelin in tumorigenesis. PNAS 200198 9265-9270.

124 Jeschke U, Richter DU, Möbius BM, Briese V, Mylonas I \& Friese K. Stimulation of progesterone, estradiol and cortisol in trophoblast tumor bewo cells by glycodelin A N-glycans. Anticancer Research 200727 2101-2108.

Received 21 November 2008

Accepted 22 November 2008 